\title{
The Relationship between Egyptian Economic Reform, Corporate Governance, Firm Ownership and Firm's Value: An Empirical Study
}

\author{
Nargis Kaisar Boles Makhaiel \\ Lecuter at Accounting Departement- \\ Faculty of Commerce, Tanta University
}




\title{
The Relationship between Egyptian Economic Reform, Corporate Governance, Firm Ownership and Firm's Value An Empirical Study
}

Dr. Nargis Kaisar Boloes Makhaiel

Lecuter at Accounting Departement-

Faculty of Commerce,

Tanta University

\begin{abstract}
This paper aims at filling prior literature gaps by empirically investigating the relationship between firm's political-economic context, corporate ownership and corporate governance; and firm's value and its affairs in Egypt as one of developing countries that has been faced rapid political and economic reform. The paper adopts interpretive approach and interviews fourth participants including: company executives; financial analysts; and stock exchange regulators to inform our understanding of the influence of the Egyptian economic reform on firm's value and affairs. The results show that the economic reform resulted in increased institutional ownership that is capable of better monitoring and governing managerial behaviour and decisions and hence it has become one of the important mechanisms in Egyptian corporate governance. This, in turn results in improvements in company's operational performance, long-term profitability, management reputation, competitive position, market share, financial position, growth rate, and quality of financial reports. All, in turn, have positive impact not only on firm's value and its survival, but also succeeding economic transition and flourishing the entire economy. This paper contributes to literature by: highlighting the mutual interaction between economic enterprises and their context in where they operate; providing insights into how the quality of financial reports can vary according to ownership structure; documenting there is no "one-size-fits-all" corporate governance approach which can be generalised worldwide; concluding the positive role of institutional shareholders in Egyptian firms and Egyptian economy; revealing that exercising corporate governance by institutional shareholding matters in emerging markets because of lack of other governance practices; and initiative in the use of
\end{abstract}


interpretive methodology and drawing on new institutional sociology (NIS) theory.

Keywords: Corporate Governance; Institutional Ownership; Managerial Ownership; Blocked Ownership; Economic Reform; Egypt.

\section{Introduction}

In a world characterised by conflict of interests among stakeholders in the corporate structure, there is no surprise to observe tremendous international financial scandals and corporate failures e.g. Enron, WorldCom, Global Crossing, etc. This conflict is emerged from three main sources: first, the separation of corporate ownership from corporate management; second, differences in goals, interests and preferences between corporate participants; third, asymmetric information where a firm's owners have no complete information on investment opportunities compared with management (Gillan and Starks, 2003, Al-Najjar, 2010 and Alves, 2012). As a result, executives are given full scope of discretion and provided with the ability to act in their own self-interest (Gillan and Starks, 2003). Meaning, executives are likely to display a tendency towards "egoism" (Solomon, 2007); by engage in opportunistic behaviour to expropriate the company's profits to maximise their own perceived self-interest at the expense of other stakeholders (Kazemiana and Sanusib, 2015). Managerial opportunistic behaviour is largely unobservable which negatively affects the quality of the corporate financial reporting (Donnelly \& Lynch, 2002; Alves, 2012, Al-Najjar, 2010); and its entire affairs. This has raised essential need for a mechanism to govern, monitor and control managerial unobservable decisions in order to align management interests with those of stakeholders (Kazemiana and Sanusib, 2015). In this regard, Gillan and Starks (2003) argue that managers' activities are potentially controlled and constrained by numerous factors that constitute and influence the governance of the corporations (hereafter CG) that they manage. Therefore, CG has sparked a wave of regulatory reform addressing governing concerns to assure appropriate protection of shareholders' interests (Alves, 2012); ensure reliable and complete financial reporting; enhance credibility of the company; support the investment environment, and benefit the economy as a whole. Meaning, CG has become one of the important factors in 
improving the efficacy of enterprises and economy (Hamdan and Al-Sartawi, 2013).

As a direct consequence, CG has recently become an important topic over the world, specifically within the emerging stock markets, including Egypt that presses for more economic resources (Gillan and Starks, 2003); because Egypt has had a fairly rapid transition in its economic system, moving from the inward-looking-based economy in favour of an export-based economy that prioritised the private sector (Farag, 2009; Kholeif, et al., 2007); and minimised government's intervention and ownership in the business sector (Hassan, 2008a, b). Accordingly, in 1991 the Egyptian government started to implement the privatisation programme by passing Public Enterprise Law 203 and its accompanying regulations (Hassan, 2008a, b; Kholeif, et al., 2007; Rahman, et al., 2002; and Wahdan, et al., 2005). That is, Egyptian government applied a comprehensive privatisation programme as a way of reforming the productivity of Egyptian enterprises; strengthening the capital market, reactivating the stock exchange's activities and its regulatory rules, and hence improving the economy (Makhaiel and Shere, 2017, 2018).

In other words, economic reform became a vital means of restoring national and international investors' trust and confidence in stock market's activities and, in turn, raising longterm funds to be channelled into projects of economic and social development so as to succeed the economic transition (Zohny, 2000, Dahawy, et al., 2002 and Makhaiel, forthcoming). Egyptian government recognized the need for strong CG mechanisms to act as catalysts in order to improve the climate of growing economy (Makhaiel, forthcoming; Gillan and Starks, 2003, Hasan \& Butt, 2009; Buallay, et al., 2017); and to reach its aspired goals by raising new foreign capitals and encouraging more Egyptians to invest in the domestic markets and stop investing abroad (Dahawy, 2007). In this vein, scholars identify two sets of CG mechanisms; internal mechanisms, e.g. board of directors; and external control mechanisms, e.g. laws and regulations (Gillan and Starks, 2003 and Al-Najjar, 2010).

A highly debated external CG mechanism, affecting the firm's CG worldwide is the emergence of institutional investors as equity owners which have become proxy for CG and one of its important mechanisms. This is due to that institutional ownership has 
potential influence on management's behaviour, performance, activity directly through their ownership, and indirectly by trading their shares (ibid). Institutional investors are sophisticated investors who have more advantages not only in acquiring and processing information that is too costly for others to acquire but also in incorporating more information about future earnings that is not reflected in current earnings (Jiambalvo, et al., 2002; Lev, 1988). Institutional investors, therefore, have great opportunity, resources, and ability to act as an efficient monitoring device that is difficult for smaller, more passive or less-informed investors (Gillan and Starks, 2003 and Al-Najjar, 2010).

Gillan and Starks (2003) point out that the influence of institutional investors on CG is increasing because of privatization policy adopted by various countries; and that ownership structures and other CG mechanisms changed across markets as a part of evolving regulatory systems in economies where the banking, capital markets, and legal systems have undergone continuous dramatic change. Thus, there is a link between the economic-political context; and CG mechanisms, firms' ownership structure, and firms' value and affairs. This relationship, to date, has not been explored yet in any context including: Egypt. A comprehensive review of prior literature conducted in emerging and developed economics- revealed that these studies either examined the influence of different kinds of ownership structure and CG practices on firms' performance (i.e. ROA\&ROE) (Al-Zaidyeen and AL-Rawash, 2015 and Khamis et al., 2015) and on the financial reporting quality (Alves, 2012 and Grassa et al., 2018); or examined the effect of privatisation and economic reform on firms' performance (Omran, 2003 and Kenawy, 2009), and on the quality of firms' financial reporting (Adhikari et al., 2013). This literature concluded mixed findings, resulting from studying various ownership structures, different CG dimensions within different political and economic contexts of developed and developing economies which in turn differ between themselves. This study is motivated primarily by such apparent gaps in prior research; therefore, it examines: 1) the extent of how corporate ownership structure and CG mechanism can be affected by reforming Egyptian political- economic context; and 2) the effect of these changes on firm's performance, value and the quality of its financial reports. 
When it comes to benchmark against prior literature, this paper makes seven-fold contributions. First, this study is the first empirical study, highlighting the mutual influence and interaction between enterprises, and their economic-political environment; that is firm's affairs can be improved by reforming the economy; and in turn the economy will benefit from improvements in firm's conditions. Thus, this research supports Abdel-Shahid's (2003) claim that there might be economic, political, contextual factors, affecting firms' performance. Second, this study provides insights into how earnings quality can vary according to ownership structure; the quality of financial reporting can be improved within institutional shareholding. Third, it confirms the positive effect of economic transition and increased institutional ownership not only on firm's performance, success and survival, but also on country's economy as whole. Fourth, it reveals that CG exercised by institutional shareholding matters in emerging markets because of lack of other governance practices such as: investors' protection of minority shareholders, board of directors, and legal environment; thus, improving CG and credibly commit to protect shareholders can compensate for a weak legal environment. Fifth, it has initiative in the use of interpretive methodology and interviews which to the best of the author's knowledge, none of prior studies used. Interpretive approach is able to capture the effect of the Egyptian context on shaping or reshaping CG practices and hence on firms' affairs and the economy. Thus, this paper responds the calls of Doupnik \& Richter (2003), Hopwood (1987), and Pfeffer \& Salancik (2003) who state that a substantial proportion of the literature does not pay enough attention to the importance of real-life context of firms which is necessary in order to gain a deeper and clearer understanding of firms' decisions and practices. It also complies with Heracleous's (2001) findings that "scholars are in need to adopt methodologies that can account for multiple, systemic and multi-directional influences on organisational performance and affairs instead of using approaches that attempt to correlate only one factor affecting firms performance". Sixth, it highlights that there is no "one-size-fits-all" CG approach which can be generalised worldwide; evidence on CG from studies of firms in developed contexts will not hold true in emerging markets. This is due to the presence of differences between the factors giving rise to CG in developing nations than those in developed nations, developing nations are known to have different political and 
economic environments than those of the developed nations; even developing or developed countries are very different between themselves. Seventh, it also has initiative in applying new institutional sociology (NIS) theory instead of agency theory which studies the phenomenon in isolation of the effect of firms' context.

The remainder of this paper is organised as follows: section 2 reviews related literature, section 3 theoretically answers the research questions; section 4 details sample selection, and research design and philosophy; section 5 reports findings; and final section concludes and discusses the implications of findings.

\section{Literature Review}

This section reviews literature, concerning the effect of firm's corporate governance, firm's ownership, and liberalised economy and privatisation programme; on firms' affairs.

\subsection{Corporate Governance and Ownership Structures}

OECD (2004) reports that proper performance of the market; lower capital cost and efficient use of firms' resources are all based on effective CG system in individual firms and across the whole economy. Empirical research indicates that better CG leads to greater firm's value and higher stock returns (Gompers, et al., 2003); higher stock market liquidity (Chung, et al., 2010); and more success in gaining profits that delivers more value to shareholders (Rosenberg, 2003). In addition, studies find that well and properly structured CG practices effectively monitor management while processing the financial reports to ensure their compliance with financial accounting system in order to maintain their credibility (Wang, 2006 and Alves, 2012). Fawzy (2004) and Bremer and Elias (2007) conclude barriers of developing CG in Egypt, including: closely held corporations; considerable state ownership in privatized companies; lack of awareness of CG concepts and benefits; lack of board independence; and weaknesses in the Egyptian economic structure.

Literature considers ownership structure of a firm as one of its important CG mechanisms because of having influential role in monitoring and constraining the opportunistic managerial behaviour while running firms. In contrast, Dahawy (2007) finds that the strongest CG practice in Egypt is the financial transparency of firms not their ownership structure. In this 
context, prior studies examine the effect of various kinds of corporate ownership, including: institutional ownership; concentration ownership; and managerial ownership on firm's performance, its profits, value and financial reporting and disclosure.

\subsubsection{Institutional Ownership}

Authors find that sound CG structure in Malaysia, Taiwan and USA gravitates institutional investors to stocks of the companies (Bushee, et al., 2010; Chung \& Zhang, 2011; Wahab, et al., 2008 and Huang, et al., 2010). However, Hamdan and Al-Sartawi (2013) provide evidence that in Kuwait institutional investors do not prefer stocks of companies that have better and effective CG structure.

Prior studies investigate the influence of institutions on different aspects of firms including: firm's financial reports and its performance; audit quality; and the accuracy of financial disclosure. Rajgopal et al. (1999) state that institutional investors are sophisticated investors who not easily be misled by manipulated earnings compared with non-institutional investors or individual investors. In this vein, several studies document that institutional ownership inhibits managers from opportunistically managing accruals; firms with greater institutional ownership publish more conservative financial reports and significantly conform with GAAPs (Velury and Jenkins, 2006; Ramalingegowda and Yu, 2012; Gillan and Starks, 2003; AlNajjar, 2010; Rajgopal, et al., 1999; and Bradshaw, et al., 2002); and do not use $R \& D$ expenses as earnings management mechanism (Bange and DeBondt, 1998).

Furthermore, Grassa et al. (2018) demonstrate that in emerging markets, institutional ownership plays a crucial role in monitoring management activities, resulting in enhancing management ability to meet the fiduciary responsibilities and, in turn, improving firm's performance. Other studies find that high proportion of institutional ownership leads to better company performance (Smith, 1996; Agrawal and Knober, 1996 and Wan, 1999). The same results are found in Bahrain (Khamis, et al., 2015); in India (Kumar, 2003); in Japan (Kaplan and Minto, 1994) and in South Korea (Solomon, et al., 2002). Moreover, literature finds that there is significant relation between domination of institutional ownership, and high profitability and value of firms in Turkey 
(Sarac, 2002); issuing more precise, accurate and less optimistically biased earnings forecasts (Ajinkya, et al., 2005); high audit quality in Jordan (Zureigat, 2011); and improved corporate social responsibility in Egypt (Soliman, et al., 2012).

Other stream of literature takes the view of passive institutional ownership as CG mechanism, based on that institutional owners are classified as transient investors who fixate on and prefer nearterm earnings; as evidenced by Rajgopal's et al. (1999) research. Porter $(1992,92)$ supports this argument, noting:

“... institutional agents are drawn to current earnings, unwilling to invest in understanding the fundamental prospects of companies, and unable and unwilling to work with companies to build long-term earnings power".

Therefore, reporting a short-term profit disappointment will lead institutions to liquidate their holdings, resulting in the possibility of a temporary decline in equity value, fearing that managers are incentivized to increase short-term profit at the expense of longterm equity value (Rajgopal, el al., 1999 and Jiambalvo, et al., 2002). This creates and increases managerial incentives to engage in earnings management (Porter, 1992; Bushee, 1998; Jiambalvo, et al., 2002). Empirical research documents that there is positive relation between institutional ownership and the use $R \& D$ expenditures, property, plant, and equipment to opportunistically manage earnings (Wahal and McConnell, 2000 and Bushee, 1998). Other studies find that institutional ownership has no impact either on exacerbating or alleviating earnings management; or on the quality of financial reporting in Jordan (Al-Fayoumi, et al., 2010); and in Portugal (Alves, 2012). In addition, Duggal and Millar (1999, p. 106) articulate:

"Institutional investors are passive investors who are more likely to sell their holdings in poorly performing firms than to expend their resources in monitoring and improving their performance".

Therefore institutions are not capable of voting against managers because of bad effect of doing so on business relationships with firms. Authors evidence that there is a negative relation between institutional ownership and company performance in Belgium (Renneboog 2000); in Bahrain (Khamis, et al., 2015) and in Jordan (Al-Zaidyeen and AL-Rawash, 2015). Grassa et al. (2018) 
also find that the product and services disclosure of Islamic Banks is negatively associated with institutional ownership.

\subsubsection{Ownership Concentration or Blocked Ownership}

Ajinkya et al. (2005) suggest, institutions are not a dominant group, their incentives and ability to generate private information and benefits are likely to be based on the percentage of the company's common stock held by the five largest institutional owners (ownership concentration or block holding). Institutions have greater influence when they have larger proportional stakes in firms (Gillan and Starks, 2003). Theoretically, an increase in ownership concentration should lead to align the interests of controlling shareholders with those of non-controlling shareholders (Buallay, et al., 2017 and Ezat and El-Masry, 2008). This results in not only eventually enhancing a company's performance and maximizing its value (Buallay, et al., 2017 and Ezat and El-Masry, 2008); but also improving the credibility of its financial statements (Dechow, et al., 1996). Empirical evidence supports this theory by finding that the existence of large shareholders is positively associated with operational and services disclosure of Islamic banks (Grassa, et al., 2018); corporations' performance (Bethel, et al., 1998 and Al-Zaidyeen and ALRawash, 2015); increased management turnover (Kang and Shivdasani, 1995; and Kaplan and Minton,1994); tighter control over executive compensation (Bertrand and Mullainathan, 2001 and Hartzell and Starks, 2003) and more quality and relevance of published annual earnings (Alves, 2012).

However, authors argue that agency problem can be increased because of concentration ownership (Abdel Shahid, 2003 and Ezat and El-Masry, 2008). When a firm's ownership concentrates in hands of only few largest shareholders who hold shares exceed $50 \%$; this leads to monopolise and control the organization by this controlling group who would seek to enhance their interests on the expense of the interests of the company itself or minority shareholders (Hasan \& Butt, 2009 and Buallay, et al., 2017). Combination of ownership and control may allow concentrated shareholders to exchange profits for private rents (Khamis, et al., 2015). Empirical evidence supports this argument by documenting adverse effect of blocked ownership on: voluntary disclosure, issuing earnings forecasts, and publishing accurate forecasts 
(Ajinkya, et al., 2005); the quality of financial reports (Velury and Jenkins, 2006 and Al-Najjar, 2010); audit quality (Zureigat, 2011) and firm's performance in Nigeria (Tsegba and Ezi-Herbert, 2011 and Khamis, et al., 2015); in Jordan (Nadia, 2004) and in Bahrain (Khamis, et al., 2015 and Buallay, et al., 2017). Others confirm these findings by demonstrating that less concentrated ownership is positively associated with firms' performance and more informative earnings in East Asian countries (Khamis, et al., 2015)

\subsubsection{Managerial Ownership}

There is no general agreement between researchers regarding the effect of managerial stock ownership on mitigating agency problem. On the one hand, authors articulate that improving firm's value is based on CEO's stock ownership (Alves, 2012). This is due to CEO's stock ownership reduces managerial propensity to involve in non-maximising behaviour and decreases its incentives to consume perquisites and expropriate shareholders' wealth; this consequently leads to not only alignment of interests of management and shareholders and reduction in agency conflicts but decreases in managerial incentives to manipulate reported information as well (Ezat and El-Masry, 2008; Alves, 2012 and Soliman, et al., 2012). It is, therefore, argued that owning a significant portion of a firm's equity by executives leads to a better firm's performance, maximised firm's value, greater shareholders' value and high quality financial reports (Alves, 2012). In this vein, studies empirically find that greater percent of managerial ownership is positively associated with earnings quality (Alves, 2012; Ali, et al., 2008; Banderlipe, 2009; Dhaliwal, et al., 1982; Ebrahim, 2007; Klein, 2002 and Warfield, et al., 1995); firms' performance (Khamis, et al., 2015); leverage ratio of the financial structure of UK firms (Short, et al., 2002).

On the other hand, Khamis et al. (2015) and Alves (2012) claim that exceeding managerial ownership beyond certain limit creates concentrated shareholders, leading to make management more entrenched and hence to work on its own private interests at the expense of minority shareholders' interests; meaning that high managerial ownership motivates executives to manipulate earnings figures in order to improve market value of their stocks. Research investigates this phenomenon and finds that higher managerial ownership is associated with more opportunistic 
behaviour of executives (Al-Fayoumi, et al., 2010; Cheng and Warfield, 2005; Warfield, et al., 1995; and Mitani, 2010); low performance of firms (Khamis, et al., 2015); unwell capital structure (debt to equity ratio) of Pakistani listed companies (Hasan and Butt, 2009) and low level of corporate social responsibility of Egyptian firms (Soliman, et al., 2012).

\subsection{Economic Reform and Privatisation Programme}

A stream of literature explores the consequences of developing countries movement towards more liberalised economy and privatisation programme on the performance of newly privatised enterprises and conclude that, in Egypt, there is a positive effect of privatisation on: economic growth (Bolbol, et al., 2005); productivity of privatised banks (Fethi, et al., 2011); performance, competitiveness, and profitability of newly privatised enterprises (Kenawy, 2009); operating efficiency, capital expenditures, and dividends (Omran, 2003).

Similarly, others conclude that privatization results in higher consumer welfare and great social welfare (Lee, et al., 2017) and more productivity of firms (Naceur, et al., 2007). In contrast, scholars find there is no substantive improvement in the performance of privatised firms in Egypt (Omran, 2004); in Bangladesh (Uddin and Hopper, 2003) and in Britain (Bowman, 2014).

Other stream of research finds positive effect of economic-political reform on accounting and financial disclosure, and the compliance with the mandatory disclosure of Jordanian listed companies and their compliance with IFRs (Al-Akra, et al., 2009\&2010) and on improving accounting of public sector accounting in Nepal and Sri Lanka (Adhikari, et al., 2013). However, HassabElnaby et al., (2003) evidences that, in Egypt, there is no relation between the privatization of state owned corporations and accounting development.

Prior studies conducted all over the world explored the influence of different factors including: ownership structures, CG practices and economic reform; on firm's performance and profitability, audit quality and earnings quality in a vacuum of the influence of firms' context. Moreover, these studies conclude mixed findings, resulting from studying various dimensions of firms' ownership and CG within different regulative, political and economic 
contexts of developed countries compared with those of developing countries which in turn differ between themselves.

\section{New Institutional Sociology Theory: The Influence of Context on Corporations' Affairs}

Hussain \& Hoque (2002) argue, new institutional sociology (NIS) is able to explain the interplay between a firm's practices and its broader social environment; thus, it is a beneficial tool for understanding the reasons that lay behind the penetration of a particular practice, policy or an environmental requirement from the firm's context into its organizational life (DiMaggio \& Powell, 1983; Moll, et al., 2006). Within the general framework of NIS, it is suggested that a firm's environmental penetration occurs because the firm is subject to pressures i.e. coercive, normative and mimetic exerted by the institutional context to incorporate and conform to those forces' requirements (DiMaggio and Powell, 1983; Meyer and Rowan, 1977; Scott, 1995). These requirements are seen as more legitimate and acceptable and are adopted by successful firms in a given domain (Carpenter \& Feroz, 2001; Meyer \& Rowan, 1977; Mezias \& Scarselletta, 1994; Palmer, et al., 1993). This paper considers only one kind of these three pressures i.e. coercive

\subsection{Coercive Pressure: The Pressure of Dominant Financial Providers}

Covaleski and Dirsmith (1988) and Powell (1985) state that "behind every institutionalized expectation lies the threat of active coercion". According to DiMaggio and Powell (1983) and Moll et al. (2006), institutional coercive pressure refers to the external pressure either formal or informal which is exerted on a firm from its environment to force it in order to adopt certain procedures or requirements. It is considered as a force for the firm to comply with other external organizations' requirements, which provide it with the necessary support and resources for continued existence, operation and success (DiMaggio \& Powell, 1983; Pfeffer \& Salancik, 2003).

In particular, this pressure can come from other organizations, such as the dominant fund suppliers, upon which a firm depends for its survival (DiMaggio and Powell, 1983). Reliance on the same and dominant financial providers significantly exerts 
pressure on firms to meet those suppliers' requirements (Thompson, 1967 - cited in DiMaggio \& Powell, 1983). This is supported by Powell's (1983) argument that "the stronger party to the transaction [financial suppliers] can coerce the weaker party [firms] to adopt its practices in order to accommodate the stronger party's needs " (cited in DiMaggio and Powell, 1983, p.154, emphasis added).

\subsection{The Consequences of Complying with the Requirements of Dominant Financial Providers}

Firms' attempt to conform to external pressures and requirements emerges from their need to enhance their legitimacy, which is essential for their ability to survive (Carpenter \& Dirsmith, 1993; Carpenter \& Feroz, 2001; Meyer \& Rowan, 1977; Moll, et al., 2006). A favourable and the most important consequence of being perceived as a trustworthy and legitimate firm is decreasing turbulence, maintaining stability, and mobilizing support from a broader range of external bodies and constituents (Carpenter \& Feroz, 2001; Collier, 2001; DiMaggio \& Powell, 1983; DiMaggio, 1988; Meyer \& Rowan, 1977; Moll, et al., 2006; Oliver, 1992; Scott, 1987; Zucker, 1987). This enables a firm to enjoy support from external resource providers, and gives it greater and more flexible access to resources, and in turn buffers it from failure and enhances its chances of success and survival prospects in the long term (Carpenter \& Feroz, 2001; DiMaggio \& Powell, 1983; DiMaggio, 1988; Meyer \& Rowan, 1977; Moll, et al., 2006; Oliver, 1992; Scott, 1987; Zucker, 1987). Arthaud-Day et al. (2006) and Suchman (1995) assert that key audiences and financial resource providers are most likely to support and supply resources to desirable, proper, legitimate and trustworthy firms. The corollary of this is firms which lack legitimacy may be considered as "negligent, irrational, unnecessary" and unacceptable by the capital market (Meyer and Scott, 1983 cited in Deephouse \& Carter, 2005; Meyer \& Rowan, 1977). Losing the confidence of market participants leads to fundamental disturbances in resources flows (Arthaud-Day et al., 2006). This is because outsiders, e.g. dominant investors, will attempt to disassociate themselves from these firms lacking legitimacy in order to protect themselves from potential losses and "negative contagion", and will invest in other legitimate firms instead (Suchman, 1995), taking with them necessary financial, social and intellectual 
capital, which threaten firms' ability to long term survive (Arthaud-Day, et al., 2006).

\section{Methodology and Method}

This paper adopts an interpretive approach; consequently, data collection process involves interviewing a total of $\mathbf{4 0}$ participants, who were divided into three categories namely firms' executives, investors [financial analysts ${ }^{1}$ as surrogate of investors] and stock exchange regulators (hereafter, EGX)[insert tables I1:I3; participants' demography]. The researcher chose these groups because of a need to analyse opinions and views of those who witness and are involved in investment decisions in order to provide evidence about the impact of the investment decisions of dominant ownership on firm's affairs and its value.

Executive group makes up $50 \%$ of the interviewed participants. It consists of executives from five different companies, including three industrial companies ${ }^{2}(50 \%)$ and two service companies ${ }^{3}$ $(50 \%)$. Investors or financial analysts ${ }^{4}$ make up $35 \%$ of the total interviewees. Finally, the EGX regulator group makes up $15 \%$ of the total interviewed sample (inserts figure1: Percentages of the Categories of Respondents). This diversity was an attempt to maximise the difference within the sample (Glaser and Strauss, 1968 cited in Lewis and Ritchie, 2003), and hence create a representative and inclusive sample relative to the parent population for the sake of enhancing the validity of the study (Lewis and Ritchie, 2003). This diversity also helped the researcher to improve the construct validity of the interviews using "triangulation" in which all interviewee answers are crosschecked against other interviewee answers. In this way, the researcher can be confident that the interviews correctly measure what they are intended to measure. In addition, using a diverse sample facilitated the collection of rich data and helped identify

\footnotetext{
1 The researcher depended on financial analysts instead of investors; because in Egypt there are no sophisticated investors who are able to make investment decisions themselves, so that they mainly resort to financial analysts and brokerage firms.

${ }^{2}$ Industrial companies comprise textile, pharmaceutical and motor industry companies.

3 Service companies include restaurant and hospitality and securities brokerage companies.

${ }^{4}$ Investors group consists of large companies and medium-sized companies
} 
the themes shared between different participants regarding the phenomenon under study (Patton, 2002 and Ritchie et al., 2003).

To enhance the validity of interviews, the researcher relied on not only purposeful sampling, but also taking into account the following arguments when choosing the sampled participants and conducting interviews. Most of interviewees were senior employees who were likely to exhibit high levels of integrity. Also, the researcher interviewed analysts, and the stock exchanges' authorities who had no incentive to be untruthful. In addition, the researcher made comparison between the answers of each interviewed group with others to test that all interviewees were providing reliable information. Also, interviewees were asked similar questions in different ways in order to check the validity of the responses of one group against the answers of others. Moreover, it is important for the researcher to limit the amount of bias during the data analysis to enhance the research's validity (Lewis \& Ritchie, 2003). Therefore, this research employs "comprehensive data treatment" by incorporating, analysing, and inspecting all the data collected without exception, and by avoiding the use of brief "conversations, snippets" from interviews (Bryman, 1988; Silverman, 2000, 2010). Data were then analysed by using Ritchie \& Spencer's (2002) thematic $\operatorname{approach}^{5}$.

The sample of this research is chosen from the working population or sample frame which refers to the full range of relevant participants and groups available to serve the research purposes (Ritchie et al., 2003), which may be practically used as units of analysis, i.e. the sample units (Zikmund et al., 2010). The most convenient source for the sample frame is the lists published on websites useful for creating a sample of organizations or professionals (Ritchie et al., 2003 and Zikmund et al., 2010). In

\footnotetext{
${ }^{5}$ This approach requires the implementing of the following steps. First, the researcher constructed a thematic framework or index based on the research questions, and interview questions. Indexing was next step, in which the researcher systematically applied the thematic framework to the gathered information in its textual from. Next, the researcher transferred the data from its original contexts to be rearranged in accordance with the headings and subheadings drawn from the thematic framework -i.e. according to each interview question. Mapping was the final step in which the researcher focused on interpreting the data and provided answers to the research questions.
} 
light of this guidance, the researcher depended on the EGX and Egyptian Financial Supervisory Authority's (EFSA) websites for choosing securities brokerage firms, EGX-listed companies, in addition to personal relationships and friendships that were used to recruit other participants, e.g. some of the participants from non-listed companies and especially, EGX's regulators.

\section{Data Analysis, Results and Findings}

Zikmund et al. (2010) argue that human beings' experiences and practices should be explored within the context in which those people live and work, because factors that influence people's behaviour and decisions are inherently shaped by their context. Consequently, an exploration of the influence of ownership structure on corporate governance, and on corporate's behaviour and affairs within Egyptian context needs to be based on the adoption of qualitative research methodology in order to deeply delve into the views, beliefs and opinions of three groups of respondents: executives from manufacturing and service firms; and financial analysts; as well as the opinion of stock market regulators.

\subsection{The Effect of Political-economic Environment on Corporate Governance, Ownership, and Affairs}

Providing evidence about the effect of the political-economic transition on the CG and firms' decisions and affairs necessitates considering: first, the effect of the environmental changes on firms' shareholding and their CG; and second, the influence of these changes on firms' value and affairs.

\subsubsection{The Effect of Economic-political Reform on CG}

Egyptian government had made significant efforts towards restructuring the economy and introducing comprehensive economic-political reform, involving the transition to a freemarket-based economy, this economic transition had have effect on ownership structure of firms in terms of increases in institutional ownership at the expense of individual investors; as demonstrated by Abdel Shahid (2003: p10- emphasis added), stating that

"The large privatization deals as well as other deals involving transfer of ownership that ... were mainly conducted by 
institutions...The Egyptian market has been long characterized by the dominance of private investors [individual investors] more than 60 percent. However, the market structure changed ... whereby institutions constituted 67 percent of the market".

Analysts and regulators generally agreed that: "In Egypt ... there were no institutional investors but after the economic transition this kind of investors has started appearing and has been increasing" (FAN9). REG1 continued stating: "Egyptian market's structure consisted of $\mathbf{6 0 - 7 0 \%}$ retail [speculators or individuals] and $30-40 \%$ institutions ... nowadays the percentage of institutional investors has risen to more than $50 \%$... the current political-economic situation has caused the retail percentage to fall to less than $50 \%$..." . When asked about the effect of increased institutional ownership on CG, analysts stated that: "CG system comprises different mechanisms ... after the privatisation programme had been applied institutions became key players in the Egyptian market and started playing important role as external CG mechanism in Egyptian economy" (FAN1). Executives also asserted that: "Economic-political reform ... resulted in several achievements including: increased role of institutions as dominant ownership in the Egyptian CG ..." (MAN13, a financial manager).

\subsubsection{The Effect of Practicing CG by Institutions on Firm's Affairs and Value}

When asked about the potential influence of practicing CG by institutions on the firm's affairs, performance and value, regulators demonstrated that: “... corporation's ownership structure undoubtedly has essential effect on a firm's performance and its prospects through necessary conditions they require being willing to invest or to continue investing in a firm ..." (REG3). The researcher started asking about investors' investment requirements, all participants were quick to state that: "in EGX there are two kinds of investors: institutional investors and individual investors ... each group has different requirements to invest in a certain firm which, in turn, affect this firm's affairs ..." (REG2). 
Therefore, highlighting the influence of institutional investors' requirements on firm's affairs and on the whole economy necessitates:

1) Comparing between the requirements of institutional ownership with those of individual investors.

2) emphasizing the significant impact of the requirements of institutional ownership on firm's affairs and in turn on the whole Egyptian economy

\subsubsection{Comparison between Investing Requirements of Institutional Investors with Those of Individuals}

Individual or short-term investors are speculators, traders, transient and temporary investors who hold a small number of shares within a large quantity of firms. However, institutional investors, long-term investors or sophisticated investors are those who hold a large number of shares in a few firms over a longterm. Each kind of ownership has different investment expectations.

\subsection{The Expectations of Individual Investors}

Individual investors are interested in certain issues that should exist in a potential investee firm including: fluctuations in stocks' market value and publishing short term profits.

\section{Fluctuations in Stock Market Value}

Speculators are transient investors who buy and sell securities in light of fluctuations in the market value of firms' stocks and who are prepared to engage in risky business ventures in the hope of making large gains. Most of interviewee groups agreed that this kind of investors are seeking to gain profits which result from upward and downward movements in companies' stock prices. The greater the fluctuations in the stock price, the more willing speculators are to trade in such stock, as indicated in the following regulator's quotation:

"... Speculators always care about the stock price (they buy the stock at a price of 1 pound to sell it for 2 pounds)... speculators seek to benefit and profit from the stock price fluctuations" (REG4). 
Regulators (REG6) took the view that “... Speculators look for money they neither prefer fundamentally strong firms nor think about too long-term an investment... [rather] they are interested in very short-term deals ... they buy today to sell tomorrow in order to achieve gains". Consequently, analysts stated that "...speculators are more interested in the technical analysis i.e. the stock price movements than the fundamental analysis i.e. financial analysis" (FAN 9).

\section{Incomprehensive View of the Firm}

Analysts asserted that speculators do not care about the firm's internal affairs such as: management plans, policies and strategies, or the international and global influences on firms. It is likely that they will not even know the name of the firm in which they are buying stock.

“... Speculators do not care about the firm's circumstances... they do not even care about the firm's name ... because they will not continue investing in this firm" (FAN4).

\section{Short-term Profits/ Low Quality of Financial Reporting}

As argued by Bushee (1998), due to the fact that speculators behave as "traders" and not as "owners", they are involved in "momentum trading" and sell (buy) a firm's stock based on announcements of bad (good) short-term published earnings. Executives consistently agreed on this issue and claimed that: "Short-term investors care about short-term profit and not activities designed to enhance the firms' future performance, e.g. $R \& D$, and hence make investment decisions according to such information" (MAN16: financial manager). Thus, the managers' and regulators' groups noted that if speculators hear that a company is going to lose money without seeing any figures, they will sell the stocks ...This behavior is more relevant and applicable to the traders not investors" (MAN5, a financial controller). Hence "the price of the stocks which attract speculators fluctuates significantly each day" (REG2).

Consequently, Bushee (1998) articulates, speculators' concern with short-term profit creates incentives for executives to steer or manage earnings upwards in order to avoid a disappointing earnings announcement, which encourages traders to sell their shares, leading to a decline in the firm's stock price. Executives 
commented that "... Company's capital is not affected by the stock price on the EGX ... An increase or decrease in the stock price of the firm because of speculators' behavior does not increase or decrease its current capital... But the stock price has an influence on the firm's capital when the company intends to issue new stocks in order to attract new capital; in this case I have to place more emphasis on short-term profits to avoid the negative effects of speculators' decisions" (MAN8, CEO).

\subsection{The Expectations of Institutional Investors}

Executives specified the expectations of institutional ownership, stating that "... institutional investors are long-term investors, holding a large number of shares over a long-term ... so that they are interested in long-term profits, highly valued firms, better operational performance, highly reputed management, powerful competitive position, greater market share and growing industries and firms ..." (MAN9:financial manager).

\section{Strong Financial Position}

Financial analysts demonstrated that "one of institutions' requirements is investing in a firm with strong financial position" (FAN3). So that interviewees indicated that: “... firm's reliance on institutional investors as the basic source of funds is considered to be a major reason explaining why they act as an important driver behind executives' intention to care and improve the financial position..."(REG 2). Executives confirmed, “... Whoever funds my project is the important person, whom I take care to achieve and provide him/her with strong financial position which enables me to get such money" (MAN3, a financial manager).

Analysts continued stating that "...Without strong and healthy financial position, long-term shareholders will withdraw their money, resulting in the closure of the firm and an end to its work" (FAN 12).

\section{Highly Valued Firm}

Instituions require investing in a highly valued company, therefore Bushee (1998) asserts that institutional investors monitor managerial opportunistic behaviour in order to avoid a negative response from the stock market and hence to escape any negative effects on the firm's value in the long-term that can 
result from reporting losses, decreases in the annual reported earnings and ignoring long-term profits. Analysts highlighted this point by stating that "Initial forecasts made by the financial analyst and investors are firstly influenced by reporting losses or profits ..." (FAN14). "Reporting long-term profits is very important for me ... it reflects the value of the firm ... so I start my evaluation of a firm by analysing its financial reports over 3-5 consecutive years. Those reports include: balance sheet; loss and profit statement; and cash flows ... to be sure about its ability to report long-term profits" (FAN9). Therefore regulators confirmed that reporting long-run profits is a requirement of investors. "Investors in any part of the world are sensitive to net profits" (REG1); because "... reporting profits means that [investors] achieve two kinds of gains: capital gains in terms of an increase in the stock price (I bought it for 10 pounds and its market value became 15 pounds); and revenues in terms of dividends" (REG5). Executives asserted, "... investors, either current or expected, are the most important party pushing me to report profits, [because] they care about achieving profits in order to increase their wealth and get returns on their investment" (MAN6, a financial manager).

Executives took the view that "I must be concerned with the stock market's reaction to the published long-run profits. This provides implicit information to investors and to the whole market ... as a direct result investors will trust the firm and prefer to purchase my stock" (MAN15, a chairman of the board of directors). "If an investor has a variety of opportunities for investment, he/she will choose the best" (FAN8). This leads to a high demand for the stock due to considerable enthusiasm among market participants for buying such highly valued stocks. Analysts pointed out that the "stock price is the wealth of investors" (FAN11). It is necessary for firm's management to enhance the stock price and the company's value on the EGX and hence investors' wealth which they require" (MAN20, chairman of board of directors). A firm "continuously reporting profit appears strong in the EGX" (REG4). In other words, a "firm's success and its weight in the stock market are reflected in its profit figures" (FAN 13). Executives confirmed that firms that succeed in increasing their profits from one year to another or at least preventing profits from decreasing are considered highly trustworthy and are evaluated as such in the stock market. As a result, analysts 
expected managers to "try to listen to institutional investors' requirement ... in order to prevent over sale of such stock which leads to a reduction of the stock price in the market and reduction in firm's value..." (FAN15).

Analysts mentioned that "reporting losses reduces the value which I predict for the market value of the firm's stock ..." (FAN11). "... if investors see that analysts value the stock at 18 pounds and its price on the market is 22 pounds, they will sell it ... Investors compare between the value given by analysts and the market price of the stock" (FAN12). Regulators asserted that, in the case of unfavourable financial results, investors will "doubt the share", and hence will be willing to sell it. CEO 19 portrayed "reporting losses [as] a red line for investors to avoid investment in such a firm"; "why would I enter or invest in a firm which is losing?" (REG6). Meaning, current investors will sell the stocks of a firm that has reported losses and attempt to search for a better opportunity; and "... potential investors will never buy such stock ... and start looking for another opportunity... there is a whole market full of many investment opportunities". (REG2). Thus, regulators expressed an expectation that "as long as the firm at least maintains its profit or increases it, it will be a well-known firm ... its stock price increases [thus] whenever the firm needs money it will find people willing to buy its stock because of its enhanced market evaluation" (REG1). In contrast, analysts indicated that: "... a lower stock price results in many negative factors which encourage management to enhance it. One of these is the negative effect on the firm's ability to acquire additional capital through the EGX due to the bad reputation of the stock ..." (FAN7).

\section{High Quality of Financial Reporting}

It has been evidenced that investors require long-term profits due to their concern with a firm's market value and their own wealth. Analysts pointed out that "... institutional investors are able to gather adequate information in order to determine the quality of management decisions ... so that they can implicitly curb managerial opportunistic behaviour, enabling them to prevent managers from taking actions which result in an increase in shortterm financial results at the expense of the firm's long-term value ..." (FAN8). Executives added that "... institutions are sophisticated investors who analyze the profits to know its 
components, because they put more emphasis on operational cash flows, resulting from the basic activities of firms ... not on shortterm profits that can be manipulated ... this leads to reducing earnings management behavior ..." (MAN10, CEO).

\section{Growing and Expanded Projects}

Regulators saw institutions as long-term investment hunters; so they believed that "long-term investors - mutual funds - like to invest in a very strong sector which has steady growth in order to make money" (REG2). Analysts continued stating, "... investors care about the possibility of extending the company's activities, the expected growth rate and the expected cash flows. They also care about the company's field of business - whether the company operates in a growing or a shrinking industry" (FAN9). "... I analyse the industry which the firm trades in, to determine whether it is a new and thriving industrial sector or one that is in decline etc. ... I also have to know the growth rate of the firm's industry itself ..." (FAN14). Thus, both analysts and EXG regulators indicated that "when a firm reports a profit and does not announce dividends, like the Naguib Sawiris group, this is a very good indicator for me as an analyst; at the level of fundamental analysis, it is very much appreciated for a firm not to pay out dividends but to reserve the profits achieved for new investment projects and further expansion. This indicates more growth in the future and greater increases in the stock price and investors' wealth." (FAN2).

\section{Powerful Competitive Position and High Market Share}

The analysts pointed out that "... from the investors' perspective, investors care about the firm's ability to survive and flourish in the long-term; so they are interested in finding out about R\&D activities as key requirements for enhancing firm's powerful competitive position, its market share, and its growth (FAN10). Executives confirmed that "investors who want to make a longterm investment in a company will undertake very deep analysis of the internal aspects of a firm and its circumstances in order to establish whether or not it represents a good project in which to invest ... they, therefore, will be concerned with many issues, including opportunities for the company to be expanded, its competitive position, its market share, and its ability to generate profits ..." (MAN6, a financial manager). 


\section{Reputed Management}

Analysts highlighted that "as a financial analyst a basic part of my analysis and evaluation of a firm is the idea of the firm's management effectiveness and the scope of its success ..." (FAN7). Executives asserted that 'investors' trust can be increased and the stock price of a firm can be inflated when investors know that a company is running well" (MAN5, a financial controller). Stock exchange regulators added that "institutions care about long-run success and survival of the investment opportunity... so they deeply look for managerial policies, strategies and plans for future to be sure that firm will go in the right track ..." (REG3).

\section{Operational Cash Flows}

Financial analysts indicated another essential requirement for institutional investors while evaluating investment opportunity which is the operational cash flows. "Institutions always look beyond the financial results to know whether these profits come from the basic course of firm's business and its operational activities or they result from other sources such as: investment or finance activities" (FAN8). Therefore, when a firm reports losses this might not affect institutions investment decisions, because "... investors put more emphasis on whether a company sustains real losses i.e. operational losses ..." (FAN9). In this regard, all executives and analysts believed that invested institutions subject potential investing opportunity to comprehensive analysis to demonstrate the underlying reasons for reporting losses in order to determine whether these losses result from the operational activities of the firms or from normal costs, e.g. construction/reconstruction costs, as summarised in the following respondent's comment:

"A live example I always give is the case of the Mobinil company [one of three dominant mobile phone companies in Egypt], since its inception and during the establishment process, it achieved losses for three consecutive years... a deep analysis revealed that achieving such losses was normal because of the increased structural costs involved for a startup company in the business world .... They are not operational losses ..." (MAN11, a financial manager).

In addition, the analysts group added that detailed analysis demonstrates whether reporting losses is due to ineffective 
management decisions or to problems related to the industry sector of the firm. Losses can result from "temporary external circumstances" and "emergencies".

Therefore, "long-term investment depends on full analysis which can show whether there are reasons that justify reporting losses, such as emergencies which are beyond the control of the firm e.g. sudden increases in the cost of raw materials, labour and in the currency price or a sharp reduction in the sale price ..." (FAN3). Regulators went further and added that, "... achieving losses [can] result from a drop in the international economy... thus a firm's poor performance may result from external factors rather than internal effects which can be confirmed by deep analysis ..." (REG2). Analysts agreed, "I consider the global issues e.g. economic or political. I also study the market and the overall economic and political situation of the country, such as whether there is recession or inflation ..." (FAN14). Regulators and analysts collectively summarised that "profit is one of the important evaluative aspects of the firm but it is not the only indicator ... other indicators are the firm's management effectiveness, future prospects of the business, its profitability, economic and political situations and international issues; overall those are all important factors. Thus the price of stock is a function of various news and information, (REG1).

To that effect, regulators noted that "stock belonging to firms like the CIB bank, the majority of which is owned by institutions, have no fluctuations, and the stock price has steadily increased (i.e. it increases by 50 pence or 1 pound a month); because they do not sell their shares easily" (REG2).

\subsubsection{The Impact of the Requirements of Dominant Institutional Ownership on Firm's Value and on Economy}

The strength of practicing CG by institutional investors in Egypt has raised from their positive requirements to invest in a company, leading to managerial struggle to accommodate these requirements. Analysists summarized this point by highlighting that "generally institutions have power on firm's affairs ... whereas individuals do not have the same ... institutions' power has been increased after the economic reform ... institutional ownership is considered as influential and beneficial CG technique because of its positive effect on: company's profits, 
financial position, operational activities, management reputation, financial reporting quality, competitive position, market share and growth rate ... all, in turn, drive firm's success and flourish its prospects ... which, in turn, lead to great success and flourish for the whole economy ..." (FAN8). Therefore, analysts perceived that: "the domination of institutions in the stock market has positive effects not only on the firm's performance and its success and survival but also on the country's stock market and its economy by increasing investors' trust, national and international, in the Egyptian firms and economy ..." (FAN3). Analysts asserted, "the most successful firms are the firms which have strategic investors who are able to improve the firm's performance ... this, in turn, has favourable effects on the stock market and the national economy ... however, the less successful firms are those which have separated ownership ..." (FAN1).

Regulators confirmed the essential role of institutions in Egyptian economy by stating that: "CG in emerging economics needed be practiced by institutional investors ... where inadequate minority shareholder protection is not exist;... leading to enhance investors' confidence in Egyptian economy ..." (REG1).

\section{Conclusion and Discussion}

This paper finds that moving to more liberalized economy has had significant impact on firm's ownership structure in terms of increases in institutional ownership at the expense of individuals or speculators ownership. Dominant institutional shareholding has become important mechanism in governing and controlling management by pushing it to accommodate their requirements. These results are in consistent with research conducted by Soliman et al., (2012); Abdel Shahid, (2003); Mensah, (2002); Fawzy, (2004); and Bremer and Elias, (2007). However, they are in contrast with Dahawy's (2007) findings. This paper continues finding that complying with institutions' requirements leads to managerial decisions that result in improvements in firm's operational performance, financial position, competitive position and market share, market value, management reputation, growth rate and quality of financial reports; all lead to positive effect on Egyptian economy as a whole.

The findings of this paper contribute to literature in many ways by: highlighting mutual interaction between enterprises and their 
contextual environment; providing insights into how earnings quality can vary according to ownership structure; confirming the positive effects of economic transition and increased institutional ownership on firm's affairs and on country's economy; highlighting that there is no "one-size-fits-all" CG approach which can be generalised worldwide; revealing, CG exercised by institutional investors matters in emerging markets because of lack other governance practices; and finally, initiative in applying new institutional sociology (NIS) theory, and interpretive research philosophy and interviewing method for collecting data.

The findings reported in this paper can be in importance for four parties: investors; firms; regulators and policy makers; and government. First, investors who are looking to invest in the studied country, Egypt, and who consider emerging markets as immature in regard to the laws protecting minority shareholders may find this study useful as it provides them with evidence about improving CG as a means, ensuring fundamental protection for their rights. Also, this study provides them with analysis of how firms' affairs have been improving due to ongoing policies that attempt to reform Egyptian economy; improve CG regulations and mechanisms; and restructure firm's ownership. All provide investors with complete portrait to determine whether Egypt has an appropriate investment climate. Second, Egyptian companies may benefit from the findings of the study to improve their ownership structure through promoting institutional shareholding instead of individual and scattered ownership. Third, regulators concerned quality of financial reporting such as the Capital Market Authority in Egypt and other emerging countries in that region can use the findings of the study to improve CG regulations and practices through the optimization of ownership structure to enhance FRs quality. Finally, the results can be in importance for government of emerging economies including: Egypt to seek applying well-structured CG, widely practiced by institutions to boost investors' confidence in a country's economy; deepen capital markets; facilitate access to a wider pool of investors and raise investment rates; encourage the growth of the private sector by channelling finance to its projects, generate profits, and create job opportunities; all secure high and sustainable rates of growth of Egyptian economy

This research has a number of limitations: first, the results were based on responses from $\mathbf{a}$ 
small number of interviewees; thus, they should be interpreted with caution, given the limitation of the employed purposive sampling technique. Second, this study adopted the NIS theory and interpretive approach which helped identify the effect of economic transition on firm's ownership, CG and its affairs in the particular setting, i.e. Egypt. This implies that the primary limitation of this study is in the application of the results to other settings. This calls for future research investigating this phenomenon in other settings which have so far been underresearched in this area either using the same theory and research philosophy or by adopting others. Third limitation is that the research participants were limited to three groups: managers; financial analysts, and regulators. Although their views were very useful in serving the paper aims, during the data analysis, it emerged that it would be beneficial to include some other participants who are interested in quality CG such as foreign investors and governmental authorities. It would also be beneficial to conduct further research interviewing these interested parties besides academics and accountants. Fourth limitation is that factors affecting firms' $C G$ and their ownership are shaped and significantly influenced by economic factors. These aspects continuously change over time, implying further investigation. 


\section{Reference}

Al-Akra, M., Ali, J. and Marashdeh, O. (2009) "Development of accounting regulation in Jordan", International Journal of Accounting, 44 (2), pp. 163-186.

Al-Akra, M., Eddie, A. and Ali, M. (2010) "The influence of the introduction of accounting disclosure regulation on mandatory disclosure compliance: evidence from Jordan", British Accounting Review, 42 (3), pp. 170-186.

Abdel Shahid, Sh. (2003), "Does Ownership Structure Affect Firm Value? Evidence from The Egyptian Stock, Market", Working Paper, www.ssrn.com

Adhikari, P., Kuruppu, C. and Matilal, S. (2013) "Dissemination and institutionalization of public sector accounting reforms in less developed countries: a comparative study of the Nepalese and Sri Lankan Central governments", Accounting Forum, 37 (3), pp. 213 230.

Agrawal, A. and Knober, C. (1996) "Firm performance and mechanisms to control agency problems between managers and shareholders', Journal of Financial and Quantitative Analysis, Vol. 31, pp. 377-97.

Ajinkya, B., Bhojraj, S, and Sengupta, P., (2005) "The Association between Outside Directors, Institutional Investors and the Properties of Management Earnings Forecasts", Journal of Accounting Research 43(3), pp 343376.

Al-Fayoumi, N, Abuzayed, B and Alexander, D. ( 2010) "Ownership structure and earnings management in emerging markets: The case of Jordan", International Research Journal of Finance and Economics, vol.38, pp28-47.

Ali, SM, Salleh, NM and Hassan, MS. (2008) “Ownership structure and earnings management in Malaysian listed companies: the size effect", Asian Journal of Business and Accounting, 1 (2), pp89-116. 
Al-Najjar, B. (2010) "CG and institutional ownership: evidence from Jordan", Corporate Governance: The international journal of business in society, 10 (2), pp.176-190

Alves, S. (2012) "Ownership Structure and Earnings Management: Evidence from Portugal", Australasian Accounting, Business and Finance Journal, 6(1), pp.57-74.

Arthaud-Day, M., Certo, S., Dalton, C. and Dalton, D. (2006) “A Changing of the Guard:

Executive and Director Turnover Following Corporate Financial Restatements", Academy of Management Journal, 49(6), 11191136.Board of Directors Resolution No. 84 (2016), Egyptian Corporate Governance Code, Egyptian Institute of Directors (EIoD), Egyptian Financial Supervisory Authority (EFSA), pp1-69

Bange, M. and W. DeBondt, (1998) "R\&D Budgets and Corporate Earnings Targets," Journal of Corporate Finance, 4 (2), pp. 153-184.

Banderlipe, MR. (2009), "The impact of selected corporate governance variables in mitigating earnings management in the Philippines", DLSU Business \& Economics Review, 19(1), pp17-27.

Bertrand, M. and Mullainathan, S. (2001), "Are CEOs Rewarded for Luck? The Ones Without Principals Are,", Quarterly Journal of Economics 116 (3), pp. 901-932.

Bethel, J., Liebeskind, J., and Opler, T. (1998) "Block Share Purchases and Corporate Performance," Journal of Finance 53 (2), pp. 605-635.

Bolbol, A., Fatheldin, A. and Omran, M. (2005), "Financial development, structure, and economic growth: the case of Egypt, 1974-2002", Research in International Business and Finance, 19 (1), pp. 171-194.

Bowman, A. (2014), "An illusion of success: the consequences of British rail privatisation", Accounting Forum, Vol 39, pp. 51-63.

Bradshaw, M, Bushee, B. and Miller, G. (2002) "Accounting Choice, Home Bias, and US Investment in Non-US Firms," Harvard Business School Working Paper.

Bremer, J., and Ellias, N. (2007) "Corporate Governance in Developing Economies -The 
Case of Egypt." International Journal of Business Governance and Ethics, 3(4) pp. 430-445.

Bryman, A. (1988), Quantity and Quality in Social Research, Unwin Hyman, London.

Buallay, A., Hamdan, A. and Zureigat, Q. (2017) "Governance and Firm Performance: Evidence from Saudi Arabia, Australasian Accounting”, Business and Finance Journal, 11(1), pp 79-98.

Bushee, B. (1998) "The Influence of Institutional Investors in Myopic R\&D Investment Behavior”, Accounting Review, 73(3), pp.305-333.

Bushee, B., Carter, M., and Gerakos, J. (2010) "Institutional Investor Preferences for Corporate Governance Mechanisms", Working Paper: University of Pennsylvania. USA.

Carpenter, B. and Dirsmith, M. (1993) "Sampling and the Abstraction of Knowledge in the Auditing Profession: An Extended Institutional Theory Perspective", Accounting, Organizations and Society, 18(1), pp 41-63.

Carpenter, V. and Feroz, E. (2001) "Institutional Theory and Accounting Rule Choice: An Analysis of Four US State Governments' Decisions to Adopt Generally Accepted Accounting Principles", Accounting,Organizations and Society, 26(7-8), pp565-596.

Cheng, Q \& Warfield, TD. (2005) "Equity incentives and earnings management', The Accounting Review, 80(2), pp 441-476.

Chung, K., Elder, J. and Kim, J. (2010) "Corporate Governance and Liquidity", Journal of Financial and Quantitative Analysis, 45 (1), pp. 265-291.

Chung, K., and Zhang, H. (2011) "Corporate Governance and Institutional Ownership", Journal of Financial and Quantitative Analysis, 46 (1), pp 247-273.

Collier, P. (2001) "The Power of Accounting: A Field Study of Local Financial Management in a Police Force", Management Accounting Research, 12(4), pp.465-486.

Covaleski, M. and Dirsmith, M. (1988) “An Institutional Perspective on the Rise, Social Transformation, and Fall of a University Budget Category", Administrative Science Quarterly, 33(4), pp.562-587. 
Dahawy, K. (2007) "Developing nations corporate governance: the story of Egypt", The American University in Cairo, Available at https://www.researchgate.net/publication (accessed at June 2018).

Dahawy, K., Merino, B. and Conover, T. (2002) “The Conflict between IAS Disclosure

Requirements and the Secretive Culture in Egypt", Advances in International Accounting, 15, pp 203-228

Dechow, P., Sloan, R. and Sweeney, A. (1996) "Causes and Consequences of Earnings Manipulation: An Analysis of Firms Subject to Enforcement Actions by the SEC", Contemporary Accounting Research, 13(1), pp.1-36.

Deephouse, D. and Carter, S. (2005) "An Examination of Differences Between Organizational Legitimacy and Organizational Reputation", Journal of Management Studies, 42(2), pp.329-360.

Dhaliwal, DS, Salamon, GL \& Smith, ED. (1982) "The effect of owner versus management control on the choice of accounting methods", Journal of Accounting and Economics, 4, pp. 41-53.

DiMaggio, P. (1988) Interest and Agency in Institutional Theory, in Zucker L. (Ed.), Institutional Patterns and Organizations: Culture and Environment, MA, Ballinger, Cambridge, pp. 3-21.

DiMaggio, P. and Powell, W. (1983) "The iron cage revisited: institutional isomorphism and collective rationality in organizational fields", American Sociological Review, 48 (2), pp. 147-160.

DiMaggio, P. and Powell, W. (1991), Introduction, in Powell, W. and DiMaggio, P. (Eds.), The New Institutionalism in Organizational Analysis, University of Chicago Press, Chicago,pp. 1-38.

Doupnik, T. and Richter, M. (2003), Interpretation of Uncertainty Expressions: A Cross-national Study, Accounting, Organizations and Society, 28(1), 15-35

Duggal, R \& Millar, JA 1999, 'Institutional ownership and firm performance: The case of bidder returns', Journal of Corporate Finance, 5, pp103-17. 
Ebrahim, A2007, 'Earnings management and board activity: An additional evidence', Review of Accounting and Finance, 6 (1), pp4258.

Ezat, A., and El-Masry, A. (2008) "The impact of corporate governance on the timeliness of corporate internet reporting by Egyptian listed companies", Managerial Finance, 34 (12), pp. 848867

Farag, S. (2009), The Accounting Profession in Egypt: Its Origin and Development, The International Journal of Accounting, 44(4), pp. 403-414.

Fawzy, S. (2004) "How Does Corporate Governance in Egypt Compare with Selected MENA and Emerging Markets?", The Egyptian Center for Educational Studies, Cairo University, June.

Fethi, M., Shaban, M. and Weyman-Jones, T. (2011) "Liberalisation, privatisation and the efficiency and productivity of egyptian banks: a non-parametric approach", The Service Industries Journal, 31 (7), pp. 1143-1163.

Gillan, S., and Starks, L. (2003) "Corporate Governance, Corporate Ownership, and the Role of Institutional Investors: A Global

Perspective", Journal of Applied Finance, Fall/Winter, pp.4-22 .

Gompers, P., Ishii, J., and Metrick, A. (2003) “Corporate Governance and Equity Prices", Quarterly Journal of Economics, 118, (1), 107155

Grassa, R., Chakroun, R., Hussainey, K. (2018) "CG and Islamic banks'products and services disclosure", Accounting Research Journal, 31 (1), pp.75-89

Hamdan, A., and Al-Sartawi, A (2013), "Corporate Governance and Institutional Ownership: Evidence from Kuwait's Financial Sector", Jordan Journal of Business Administration, 9 (1).

Hassan, M. (2008a) "The Development of Accounting Regulations in Egypt: Legitimating the International Accounting Standards", Managerial Auditing Journal, 23(5), 467-484. 
Hassan, M. (2008b) "Financial Accounting Regulations and Organizational Change: A Habermasian Perspective", Journal of Accounting \& Organizational Change, 4(3), 289- 317.

Hasan, A., Butt, S. (2009) "Impact of Ownership Structure and CG on Capital Structure of Pakistani Listed Companies", International Journal of Business and Management February, 4(2), pp. 50-57.

Hartzell , J. and Starks, L. (2003) "Institutional Investors and Executive Compensation," Journal of Finance, LVIII (6)

HassabElnaby,R., Epps, R and Said, A. (2003)"The impact of environmental factors on accounting development: an Egyptian longitudinal study", Critical Perspectives on Accounting, 14 (3), pp. 273-292.

Hawkamah and the Organization for Economic Co-operation and Development (OECD) Words to Action: The Next Regional Corporate Governance Challenge, Hawkamah's 6th Annual corporate governance conference, 31 October - 1 November 2011 in Dubai, the UAE.

Heracleous, L (2001) "What is the impact of corporate governance on organizational performance? Corporate Governance: An International Review, 9(3), pp 165:173.

Hopwood, A. (1987) "The Archeology of Accounting Systems", Accounting, Organizations and Society, 12(3), 207-234.

Huang, H., Wang, Ch., Lin, K., and Jhao, W. (2010), "Does Corporate Governance Affect Institutional Ownership and Share Repurchase Decisions?, Global Journal of Business Research, 4 (4), pp. 35-40.

Hussain, M. and Hoque, Z. (2002) "Understanding non-financial performance measurement practices in Japanese banks", Accounting, Auditing \& Accountability Journal, 15 (2),pp. 162-183.

Jiambalvo, J., Rajgopal, S., and Venkatachalam, M., (2002)

"Institutional Ownership and the Extent to which Stock Prices Reflect Future Earnings", Contemporary Accounting Research 19(1), pp. 117-145. 
Kang, J., and Shivdasani, A. (1995) "Firm Performance, Corporate Governance, and Top Executive Turnover in Japan", Journal of Financial Economics 38 (1), pp.29-59.

Kaplan, S. and Minton, B. (1994) “Appointments of outsiders to Japanese boards: determinants and Implications for managers", Journal of Financial Economics, 36, pp. 225-58.

Kazemiana , S., and Sanusib, Z. (2015) "Earnings Management and Ownership Structure", Procedia Economics and Finance, 31, pp. 618:624.

Kenawy, M. (2009) “The privatization's mechanisms and methods in Egypt: practical cases”, Journal of Applied Sciences Research, 5 (4), pp. 420-442.

Khamis, R., Hamdan, A. and Elali, W. (2015) "The Relationship between Ownership Structure Dimensions and Corporate Performance: Evidence from Bahrain", Australasian Accounting, Business and Finance Journal, 9 (4).

Kholeif, A., Abdel-Kader, M. and Sherer, M. (2007), ERP

Customization Failure:

Institutionalized Accounting Practices, Power Relations and Market Forces, Journal of Accounting and Organizational Change, 3(3), 250269.

Klein, A. (2002) "Audit committee, board of director characteristics, and earnings management", Journal of Accounting and Economics, 33 (3), pp375-400.

Kumar, J. (2003) "Does Ownership Structure Influence Firm Value? Evidence from India”, Working Paper, Indira Gandhi Institute of Development Research, India. http://dx.doi.org/10.2139/ssrn.464521.

Lee, S., Matsumura, T. and Xu, L. (2017) "Ex-ante versus ex-post privatization policies with foreign penetration in free-entry mixed markets", International Review of Economics \& Finance, 50, pp. 17.Lev, B. (1988) "Toward a theory of equitable and efficient accounting policy”, Accounting Review, 63 (1): 1-22.

Lewis, J. and Ritchie, J. (2003), Generalizing from Qualitative Research, in Ritchie and Lewis (Eds.), Qualitative Research Practice: 
A Guide for Social Science Students and Researchers, Sage, London, 263-286.

Makhaiel, N. (2018) "The Influence of Egyptian Context on The Trade-off between Earnings Management Approaches: Accounting, Operational and Investment", Journal of Financial Reporting and Accounting (forthcoming).

Makhaiel, N. and Sherer, M. (2017) "In the name of others: an investigation of earnings management motives in Egypt", Journal of Accounting in Emerging Economies, 7 (1), pp. 1-29.

Makhaieland, N. and Sherer, M. (2018) "The effect of politicaleconomic reform on the quality of financial reporting in Egypt", Journal of Financial Reporting and Accounting, 16 (1), pp. 1-26.

Mensah, S. (2002) "Corporate Governance in Ghana: Issues and Challenges" African Capital Markets Conference, December.

Meyer, J. and Rowan, B. (1977) "Institutionalized Organizations:

Formal Structure as Myth and Ceremony", The American Journal of Sociology, 83(2), 340-363.

Mezias, S. and Scarselletta, M. (1994) "Resolving Financial Reporting Problems: An Institutional Analysis of the Process" Administrative Science Quarterly, 39(4), 654-678.

Mitani, H. (2010) "Additional evidence on earnings management and corporate governance”, FSA Research Review, 6, pp1-22.

Moll, J., Burns, J. and Major, M. (2006), "Institutional Theory", in Hoque Z. (Ed.), Methodological Issues in Accounting Research: Theories, Methods and Issues, Spiramus Press, London.

Nadia, T. (2004) "Ownership Structure, Board Characteristics and Firm Profitability", Master Dissertation, Hashemite University, Jordan.

Naceur, B., Ghazouani, S., and Omran, M. (2007) "The performance of newly privatized firms in selected MENA countries: The role of ownership structure, governance and liberalization policies",

International Review of Financial Analysis, 16, pp 332-353 
OECD (2004), "OECD principles of corporate governance', available at: www.oecd.org/dataoecd/32/ 18/31557724.pdf (accessed 10 December 2005).

Oliver, C. (1992), The Antecedents of Deinstitutionalization, Organization studies, 13(4), 563- 588.

Omran, M. (2003) "Performance consequences of privatizing Egyptian state-owned enterprises: the effect of post-privatization ownership structure on firm performance", Multinational Finance Journal, 8 (1/2), pp. 73-114

Omran, M. (2004), "The performance of state-owned enterprises and newly firms: does really matter?, World Development, 32 (6), pp. 1019-1041.

Palmer, D., Jennings, D. and Zhou, X. (1993) "Late Adoption of the Multidivisional Form by Large U.S. Corporations: Institutional, Political, and Economic Accounts", Administrative Science Quarterly, 38(1), pp. 100-131.

Patton, M. (2002), Qualitative Research and Evaluation Methods, Sage, Thousand Oaks, Calif.

Pfeffer, J. and Salancik, G. (2003), The External Control of Organizations: A resource Dependence Perspective, Stanford Business Books, Stanford, Calif

Porter, M. (1992) “Capital disadvantage: America's failing capital investment system”, Harvard Business Review, pp.65-82.

Powell, W. (1985), Review: The Institutionalization of Rational Organization, Contemporary

Sociology, 14(5), 564-566.

Rahman, Z., Msadek, S. and Waly, H. (2002), Report on the observance of Standards and Codes (ROSC), Egypt, Arab Republic: World Bank Reports, World Bank, Washington, DC.

Rajgopal, S., Venkatachalam, M., and Jiambalvo, J. (1999), Is Institutional Ownership Associated with Earnings Management and the Extent to which Stock Prices Reflect Future Earnings? SSRN, Electronic Journal. 
Ramalingegowda, S., and Yu, Y. (2012) "Institutional ownership and conservatism", Journal of Accounting and Economics, 53 (1-2), pp 98-114

Renneboog, L. (2000) "Ownership, Managerial Control and the Governance of Companies Listed on the Brussels Stock Exchange" Journal of Banking and Finance, 24 (12), pp. 1959-1995.

Ritchie, J., Lewis, J. and Elam, G. (2003), "Designing and selecting samples", in Ritchie, J. and Lewis, J. (Eds), Qualitative Research Practice: A Guide for Social Science Students and Researchers, Sage, London, pp. 77-108

Ritchie, J. and Spencer, L. (2002), Qualitative Data Analysis for Applied Policy Research, in Huberman (Ed.), Qualitative Research Companion, Sage, Thousand Oak, pp. 305-329.

Rosenberg, M. (2003) "Corporate governance mechanisms and firm performance: evidence from Finland", Swedish School of Economics and Business Administration, Working Papers Sarac, M. (2002) "An Empirical Analysis of Corporate Ownership Structure in Turkish Manufacturing Sector”. Working Paper, Bogazici University, Istanbul

Scott, R. (1995), Institutions and Organizations, Sage, Thousand Oaks.

Scott, W. (1987), The Adolescence of Institutional Theory, Administrative Science Quarterly, 32(4), 493-511.

Short, H., Keasey,K., and Duxbury, D. (2002) "Capital Structure, Management Ownership and Large External Shareholders: A UK Analysis", International Journal of the Economics of Business, 9(3), pp. 375-399.

Silverman, D. (2000), Doing Qualitative Research: A Practical Handbook, Sage Publications, London.

Silverman, D. (2010), Doing Qualitative Research, SAGE, London. Smith, M.P. (1996), "Shareholder activism by institutional investors: evidence from CalPERS', The Journal of Finance, 51 (1), pp. 227 52. 
Soliman, M., El Din,M., Sakr, A. (2012) “Ownership structure and corporate social responsibility (CSR): an Empirical Study of the Listed Companies in Egypt", International Journal of social sciences, 5(1), pp 63-74.

Solomon, J., (2007), CG and Accountability, Second Edition, John Willy\& Sons, West Sussex, England

Solomon, J.F., Solomon, A. and Park, C. (2002) "The role of institutional investors in corporate governance reform in South Korea: some empirical evidence', Corporate Governance: An International Review, 10 (3), pp. 211-24.

Suchman, M. (1995), Managing Legitimacy: Strategic and Institutional Approaches, TheAcademy of Management Review, 20(3), 571-610.

Tsegba, I., and Ezi-Herbert, W. (2011) "The Relationship between Ownership Structure and Firm Performance: Evidence from Nigerian Listed Companies", African Journal of Accounting, Economics, Finance and Banking Research, 17(7), 51- 63.

Uddin, S. and Hopper, T. (2003), "Accounting for privatisation in Bangladesh: testing world bank claims", Critical Perspectives on Accounting, 14 (7).

Velury, U. and Jenkins, D. (2006) "Institutional ownership and the quality of earnings", Journal of Business Research, 59 (9), pp 10431051

Wahab, E., How, J., and Verhoeven, P. (2008) "Corporate Governance and Institutional Investors: Evidence From Malaysia", Asian Academy of Management Journal of Accounting and Finance, 4 (2), pp.67-90.

Wahal, S. and McConnell, J. (2000), "Do Institutional Investors Exacerbate Managerial Myopia?", Journal of Corporate Finance, 6 (3), pp.307-329.

Wahdan, M., Spronck, P., Ali, H., Vaassen, E. and Herik, H. (2005), Auditing in Egypt: A Study of the Legal Framework and Professional Standards, working paper, Maastricht School of Management. 
Wang, D. (2006), Founding Family Ownership and Earnings Quality, Journal of Accounting Research, 44(3), pp 619-656.

Wan, K. (1999), Do Ownership and Firm Performance Proxies Matter? An Empirical

Study of the Relation of Ownership Structure and Firm, Working paper.

Warfield, TD, Wild, JJ and Wild, KL (1995) "Managerial ownership accounting choices, and informativeness of earnings", Journal of Accounting and Economics, 20, pp 61-91.

Zikmund, W., Babin, B., Carr, J. and Griffin, M. (2010), Business Research Methods, SouthWestern, Mason, $\mathrm{OH}$.

Zohny, A. (2000), The Suitability of US Security Laws and Regulations to Serve as a Model Law for Egyptian Financial Markets, Arab Law Quarterly, 15(1), 5-47.

Zucker, L. (1987), Institutional Theories of Organization, Annual Review of Sociology, 13, 443- 464.

Zureigat, Q (2011), The Effect of Ownership Structure on Audit Quality: Evidence from Jordan, International Journal of Business and Social Science, 2 (10), pp38-46. 


\section{Appendix (I): Demography of Research Participants}

Table (I.1) Demography of Corporate Executives

\begin{tabular}{|c|c|c|c|c|c|}
\hline Manager & Position & Age & $\begin{array}{l}\text { Years of } \\
\text { Experience }\end{array}$ & Certificate & Field/ Company \\
\hline MAN1 & Financial manager & 42 & 12 & $\begin{array}{l}\text { Diploma in accounting } \\
\text { and audit }\end{array}$ & $\begin{array}{l}\text { Pharmaceutical } \\
\text { industry }\end{array}$ \\
\hline MAN 2 & Accounting manager & 37 & 9 & $\begin{array}{l}\text { Diploma in accounting } \\
\text { and audit }\end{array}$ & $\begin{array}{l}\text { Pharmaceutical } \\
\text { industry }\end{array}$ \\
\hline MAN 3 & Financial manager & 46 & 18 & MBA & $\begin{array}{l}\text { Pharmaceutical } \\
\text { industry }\end{array}$ \\
\hline MAN4 & Accounting manager & 55 & 20 & PhD in accounting & $\begin{array}{l}\text { Pharmaceutical } \\
\text { industry }\end{array}$ \\
\hline MAN 5 & Financial controller & 38 & 16 & $\begin{array}{l}\text { Master business } \\
\text { administration (MBA) }\end{array}$ & Car industry \\
\hline MAN 6 & Financial manager & 33 & 10 & MBA & Car industry \\
\hline MAN 7 & Financial controller & 30 & 8 & $\begin{array}{l}\text { Diploma in accounting } \\
\text { and audit }\end{array}$ & $\begin{array}{l}\text { Car industry } \\
\text { company }\end{array}$ \\
\hline MAN8 & CEO & 55 & 15 & PhD in accounting & Car industry \\
\hline MAN 9 & Financial manager & 50 & 25 & MBA & Textile industry \\
\hline MAN 10 & CEO & 45 & 25 & $\begin{array}{l}\text { PhD in accounting and } \\
\text { finance }\end{array}$ & Textile industry \\
\hline MAN 11 & Financial manager & 42 & 20 & $\begin{array}{l}\text { Diploma in accounting } \\
\text { and audit }\end{array}$ & $\begin{array}{l}\text { Restaurant and } \\
\text { hospitality }\end{array}$ \\
\hline MAN 12 & CEO & 49 & 22 & $\begin{array}{l}\text { PhD in accounting and } \\
\text { finance }\end{array}$ & $\begin{array}{l}\text { Restaurant and } \\
\text { hospitality }\end{array}$ \\
\hline MAN 13 & Financial manager & 28 & 6 & MBA & Brokerage company \\
\hline MAN 14 & $\begin{array}{l}\text { CEO or Managing } \\
\text { Director }\end{array}$ & 60 & 41 & MBA & Brokerage \\
\hline MAN 15 & $\begin{array}{l}\text { Chairman of the } \\
\text { Board of Directors }\end{array}$ & 55 & 27 & PhD in accounting & Brokerage \\
\hline MAN 16 & Financial manager & 56 & 35 & $\begin{array}{l}\text { Master business } \\
\text { administration (MBA) }\end{array}$ & Brokerage \\
\hline MAN 17 & $\begin{array}{l}\text { Chief executive officer } \\
\text { (CEO), }\end{array}$ & 59 & 27 & $\begin{array}{l}\text { PhD in finance and } \\
\text { economics }\end{array}$ & Brokerage \\
\hline MAN 18 & Financial manager & 55 & 10 & MBA & Brokerage \\
\hline MAN 19 & $\begin{array}{l}\text { Chief executive officer } \\
\text { (CEO) }\end{array}$ & 45 & 20 & $\begin{array}{l}\text { PhD in finance and } \\
\text { economic }\end{array}$ & Brokerage \\
\hline MAN20 & $\begin{array}{l}\text { Chairman of the } \\
\text { Board of Directors }\end{array}$ & 58 & 34 & $\begin{array}{l}\text { PhDs in accounting and } \\
\text { finance }\end{array}$ & Brokerage \\
\hline
\end{tabular}


Table (I.2) Demography of EGX Regulators

\begin{tabular}{|l|l|l|l|l|l|}
\hline Regulator & $\begin{array}{l}\text { Position } \\
28\end{array}$ & Age & $\begin{array}{l}\text { Years of } \\
\text { Experience }\end{array}$ & $\begin{array}{l}\text { Certifi } \\
\text { cate }\end{array}$ & Institution \\
\hline REG1 & - & 49 & 10 & PhD & The Egyptian Exchange \\
\hline REG2 & - & 39 & 6 & MBA & The Egyptian Exchange \\
\hline REG3 & - & 43 & 8 & MBA & The Egyptian Exchange \\
\hline REG4 & - & 42 & 7 & PhD & The Egyptian Exchange \\
\hline REG5 & - & 35 & 5 & MBA & The Egyptian Exchange \\
\hline REG6 & - & 40 & 9 & $\begin{array}{l}\text { MBA } \\
\text { \& PhD }\end{array}$ & The Egyptian Exchange \\
\hline
\end{tabular}

Table ( I.3) Demography of Financial Analysts

\begin{tabular}{|c|c|c|c|c|c|}
\hline $\begin{array}{l}\text { Financial } \\
\text { analysts }\end{array}$ & Age & $\begin{array}{l}\text { Year of } \\
\text { Experience }\end{array}$ & Position & Certificate (s) & \\
\hline FAN1 & 42 & 16 & $\begin{array}{l}\text { Vice president/ } \\
\text { researcher } \\
\text { department }\end{array}$ & $\begin{array}{l}\text { Certified portfolio } \\
\text { management }\end{array}$ & \\
\hline FAN 2 & 28 & 6 & Financial analyst & $\begin{array}{l}\text { MBA Master in } \\
\text { Business } \\
\text { Administration }\end{array}$ & \\
\hline FAN 3 & 31 & 7 & Technical Analyst & Master in economics & \\
\hline FAN4 & 35 & 12 & $\begin{array}{l}\text { Head of research / } \\
\text { financial and } \\
\text { technical analyst }\end{array}$ & $\begin{array}{l}\text { Diploma in investment } \\
\text { management / Master } \\
\text { in investment } \\
\text { management }\end{array}$ & \\
\hline FAN 5 & 35 & 15 & $\begin{array}{l}\text { Managing director } \\
(\mathrm{CEO})\end{array}$ & $\begin{array}{l}\text { Diploma in analysis } \\
\text { stock markets/ Diploma } \\
\text { in Fundamental Islamic } \\
\text { Finance }\end{array}$ & \\
\hline FAN 6 & 60 & 25 & Financial analysis & PhD in finance & \\
\hline FAN 7 & 38 & 16 & Managing director & $\begin{array}{l}\text { MBA in financial } \\
\text { analysis/ Diploma in } \\
\text { financial analysis }\end{array}$ & $\begin{array}{l}\text { Vice president of } \\
\text { the Egyptian } \\
\text { committee of stock } \\
\text { markets } \\
\text { development, vice } \\
\text { present of the } \\
\text { Egyptian committee } \\
\text { of finance and } \\
\text { investment studies. }\end{array}$ \\
\hline FAN 8 & 26 & 4 & Financial analyst & $\begin{array}{l}\text { Diploma in stock } \\
\text { market studies/ MBA in } \\
\text { markets } \\
\text { stock studies }\end{array}$ & \\
\hline FAN 9 & 30 & 10 & $\begin{array}{l}\text { Financial analyst/ } \\
\text { Manager of } \\
\text { Research and } \\
\text { Investment }\end{array}$ & $\begin{array}{l}\text { Certificated Management } \\
\text { Accounting (CMA)/ } \\
\text { Certificated financial } \\
\text { managers(CFM)/ Charted } \\
\text { Market Techniques (CMT)/ } \\
\text { Certificated Portfolio } \\
\text { Managers (CPM) }\end{array}$ & \\
\hline
\end{tabular}




\begin{tabular}{|c|c|c|c|c|c|}
\hline FAN 10 & 27 & 8 & Financial analyst & MBA & \\
\hline FAN 11 & 49 & 18 & $\begin{array}{l}\text { Financial analyst/ } \\
\text { writer in the } \\
\text { financial and } \\
\text { economic press }\end{array}$ & $\begin{array}{l}\text { MBA and PhD in } \\
\text { finance }\end{array}$ & $\begin{array}{l}\text { Member in the } \\
\text { Egyptian Capital } \\
\text { Market Association } \\
\text { ECMA, } \\
\text { member of the } \\
\text { Egyptian } \\
\text { committee of stock } \\
\text { markets } \\
\text { development }\end{array}$ \\
\hline FAN 12 & 55 & 35 & Financial analyst & Master in economics & \\
\hline FAN 13 & 48 & 12 & Financial analyst & $\begin{array}{l}\text { Diploma in stock } \\
\text { market studies/ MBA in } \\
\text { markets } \\
\text { stock studies }\end{array}$ & \\
\hline FAN 14 & 28 & 3 & $\begin{array}{l}\text { Financial analyst/ } \\
\text { Manager of } \\
\text { Research and } \\
\text { Investment } \\
\end{array}$ & $\begin{array}{l}\text { Certified portfolio } \\
\text { management }\end{array}$ & \\
\hline
\end{tabular}

\title{
Figure (1): Percentages of the Categories of Respondents
}

\author{
Decutives $\square$ Finanical Analysts $\square$ Stock Market Regualtors
}

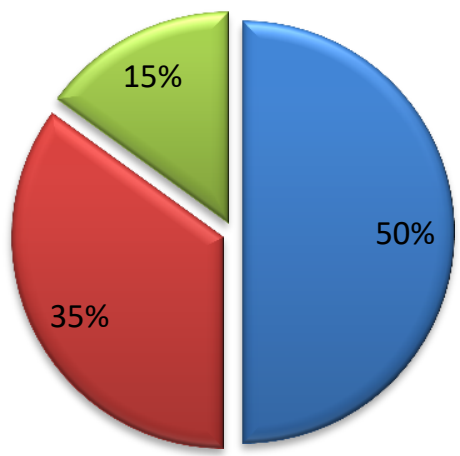

